\title{
NUEVOS DATOS SOBRE LA PRIMACÍA LINGÚÍSTICA TOLEDANA
}

1. Desde que Amado Alonso ${ }^{1}$ se ocupó, hace medio siglo largo, de la tradición que atribuye a Toledo el papel de modelo idiomático en el uso del castellano, el conocimiento de esta peculiaridad ha quedado bien asentado en la historiografía lingüística española, sin apenas merecer más atención. Algunos autores (García de Diego, Bahner), los menos, aceptan como efectiva, es decir, respaldada por sanción legal, dicha preeminencia; la mayoría considera que no pasa de ser una tradición legendaria. En cualquier caso, no se ha producido -que yo sepa- ningún intento específico de ampliar o profundizar las breves indicaciones de Alonso ${ }^{2}$.

En espera de completar y articular una crecida masa de datos ya acopiados sobre la cuestión, creo estar en condiciones de asegurar que la novedad y variedad de la información suministrada por ellos, el dilatado espacio de siglos abarcado, etc., permitirán ofrecer una imagen muy renovada respecto de la que ahora se posee.

2. Especial relieve, por diversos motivos (datación, contenido, etc.), ofrecen unas cuantas noticias que presento aquí, suficientes por sí solas de enriquecer determinados aspectos del actual conocimiento.

1 A. Alonso, El idioma español en los ideales del siglo XVI. Universidad de La Habana, 1937, 5, 32-49. El pasaje en cuestión se incorporó, sin modificaciones, a su libro Castellano, español, idioma nacional, donde también se ha mantenido inalterado en sus numerosas ediciones.

2 Me permito apuntar que el mayor aporte al tema, aun tratado secundariamente, se encuentra, si no me equivoco, en mi estudio "El establecimiento del castellano como lengua oficial", $B R A E, 1978,58,229-80$. 
El testimonio más antiguo mencionado por Alonso, sin reproducir el pasaje correspondiente, es el de Gonzalo Fernández de Oviedo ${ }^{3}$. Pues bien, existen varios testimonios considerablemente anteriores, de distinta intencionalidad en su formulación, coincidentes en manifestar la primacía toledana. Reproduciré solamente dos.

3. El primero se remonta a 1492. Con motivo de la reconquista de Granada, los Reyes Católicos incorporan con presteza a su titulatura el nombre del nuevo reino (y su símbolo, al escudo), inmediatamente después de la mención de Castilla, León, Aragón y Sicilia ${ }^{4}$. Con este motivo, la ciudad de Toledo, por medio de Alfonso Ortiz ${ }^{5}$, escribe a los reyes y, tras manifestarles la alegría pública por el triunfo, consigna sin ambages el objeto de la misiva :

\footnotetext{
Aunque en este comedio oymos una nueva que fizo mucho alterar y aun turbar nuestros coraçones [...] porque se dize averse propuesta en vuestros reales títulos Granada a Toledo (472).
}

Nada de extraño encierra este modo de proceder, si se conocen las habituales y violentas porfías suscitadas, de tiempo muy atrás, entre las ciudades castellanas a propósito del orden con que debían consignarse sus nombres en los documentos, el lugar que correspondía a sus procuradores al reunirse las Cortes, etc. ${ }^{6}$.

Toledo insta acuciosamente a los reyes para que desistan de su propósito, y aduce, entre otros, los siguientes argumentos:

Esta es la silla real donde dominaron los reyes vuestros mayores a todas las Españas y grand parte de la Francia con toda la Tyngitana en Africa. En ésta se davan las leyes, désta todas las provincias aprendian la lengua y costumbres. Aqui era la primacía y la cabeça del culto divino y de las yglesias de España (472).

Todas las circunstancias alegadas, más las restantes no copiadas, parecen ser suficientemente sabidas de antemano y aceptadas, pues no se alega prueba alguna, salvo que se quiera admitir como tal la nobleza y antigüedad de Toledo, que le confiere la primacía sobre todas las cibdades de España.

Para el propósito presente conviene destacar una de las frases recién apuntadas: Désta [ciudad] todas las provincias aprendian la lengua. Con otras

3 Puede verse en mi estudio citado en la nota anterior, $231, \mathrm{n} .5$.

- E. Benito Ruano, La prelación ciudadana. Toledo, 1972, 30.

- A. Ortiz, "Carta mensajera", en su Tratados... Sevilla, 1493. Ha vuelto a publicarse ahora por C. A. Copenhagen, Las "Cartas mensajeras" de Alfonso Ortiz: ejemplo epistolar de la Edad Media. Crotalón, 1984, 1, 467-83.

- Asunto atinadamente expuesto y aclarado en el citado libro de E. Benito Ruano. 
palabras: al menos desde 1492 Toledo se autopresentaba como modelo idiomático, sin sentirse en la necesidad de justificar esa condición.

4. La fama de Toledo en el aspecto arriba indicado queda confirmada por el testimonio de Marineo Sículo ${ }^{7}$ años después :

Adonde más polida y copiosamente se habla [el castellano] es en las principales cibdades del Andaluzía y mucho más en Castilla, principalmente en el Reyno de Toledo, aunque es toda muy prima desde la cibdad de Sevilla hasta Burgos (XXXr).

Su condición de extranjero resulta poco propicia para suponer que Marineo Sículo enjuiciaba personalmente cuestiones de propiedad lingüística; no parece, pues, que su aserto deba atribuirse tanto a la observación personal cuanto a informaciones recogidas, suficientemente variadas y contrastadas como para establecer una gradación que culmina - éste es el dato interesante- en Toledo.

5. En cuanto a la supuesta disposición de Alfonso $\mathrm{X}$ que confería efectos legales al modelo idiomático toledano, Alonso aporta la información (1629) de Tamayo Vargas, y apunta que una de las fuentes citadas por éste es Francisco de Pisa, en su Descripción de Toledo, obra publicada el año 1605, pero no reproduce su contenido. Ahora bien, Pisa no hace, a su vez, más que repetir literalmente - como en otros muchos pasajes de su libro- la Historia de Toledo de Pedro Alcocer, medio siglo anterior a aquélla, pues apareció en 1554.

Es importante exponer en todos sus términos el correspondiente texto de Alcocer, pues él proporciona la primera formulación detallada sobre el origen del privilegio toledano, pocos años antes aludido de pasada por Fernández de Oviedo ${ }^{8}$. Escribe Alcocer :

No mucho después del comienzo de su reynado se vino [Alfonso $\mathrm{X}$ ] a esta cibdad de Toledo adonde hizo Cortes, $y$ en ellas le confirmó sus privilegios [...]. Otrosi en estas Cortes ordenó el Rey que si dende en adelante en alguna parte de su reyno oviesse diferencia en el entendimiento de algún vocablo castellano antiguo, que recurriessen con él a esta cibdad como a metro de la lengua castellana, y que passassen por el entendimiento y declaración que al tal vocablo aqui se le diesse, por tener en ella muestra lengua más perfectión que en otra parte (LXXIv).

7 L. Marineo Sf́culo, De las cosas memorables de España. Alcalá, 1530.

8 Téngase en cuenta que la obra de este autor, Las Quincuagenas, donde se encuentra la alusión, ha permanecido inédita hasta el siglo pasado. De ahí que, en cuanto a posible influencia, no admita comparación con la de Alcocer.

LXVII, $10^{\circ}-2 .^{\circ}-9$ 
6. La opinión del médico zamorano Francisco López de Villalobos, contenida en su libro Los problemas (Zamora, 1543), denigradora de la excelencia lingüística de Toledo, resulta casi excepcional en el marco establecido. De ahí que, desde su exhumación por Menéndez Pidal en Orígenes del español (también en El lenguaje del siglo $X V I$ ), se venga aduciendo en los estudios sobre la lengua española en dicho siglo.

Menéndez Pidal fecha la invectiva de Villalobos en 1515, basándose -es mi creencia - en la datación expresa de la última pieza de aquel libro misceláneo. Pero estimo que tal circunstancia le desorientó. El pasaje en cuestión figura en otra sección de la obra, en un tratadillo anepigráfico que Menéndez Pidal denominó Diálogo de las fiebres. Villalobos lo compuso e incluyó - según declara en el incipit - a instancias de don Esteban de Almeyda, obispo de Astorga, interesado en la materia médica. Puesto que su episcopado se extiende de 1539 a 1542 , entre estos dos años ha de datarse el diálogo y, por tanto, la invectiva antitoledana.

Si se da por válido mi anterior razonamiento, procede descartar la fecha de 1515. Resulta molesto tener que introducir esta rectificación en el magistral panorama de la lengua española en el siglo xvi trazado por Menéndez Pidal, pero juzgo necesario hacerlo: la enmienda cronológica propuesta permite establecer una secuencia más coherente con otros testimonios de un episodio de la historia lingüística española, la rivalidad entre las dos Castillas.

F. González Ollé.

Universidad de Navarra. 